\title{
Investigation of seasonal alterations of life in the upper sea zones of Southern Primorje by the quantitative diving method
}

\author{
A. N. Golikov \& O. A. Scarlato \\ Zoological Institute of the Academy of Sciences of the USSR; \\ Leningrad, USSR
}

\begin{abstract}
KURZFASSUNG: Untersuchung der jahreszeitlichen Veränderungen des Lebens in der oberen Meereszone der südlichen Primorje mit Hilfe der quantitativen Tauchmethode. Untersuchungen über die Sukzessionen der Bodenlebensgemeinschaften in der Possjet-Bucht (Japanisches Meer) haben gezeigt, daß sowohl Zahl und Altersaufbau als auch die qualitative Zusammensetzung der Biozönosen durch den Wechsel der Jahreszeiten beeinflußft wird. Jahreszeitliche Schwankungen des Bestandes und Artenspektrums der submersen Pflanzenwelt bewirken zudem, daß die Lebensbedingungen der tierischen Bewohner des Phytals je nach dem Grad ihrer Biotopbindung mehr oder weniger stark verändert werden. Die Biozönosen des Litorals mit fester Eisbedeckung im Winter erfahren geringere Veränderungen als jene Lebensgemeinschaften, die sich in Gewässern mit driftendem Eis oder in eisfreien Gebieten entwidkeln. Arten aus tropischen, subtropischen oder angrenzenden borealen Regionen weisen eine größere quantitative Variabilität auf als Arten aus kälteren Zonen. Erstere wandern vor Beginn der Winterzeit in größere Tiefen, wo sie häufig Aggregationen bilden und in Kältestarre fallen; letztere dringen dagegen aus tieferen in flachere Wasserschichten vor, ohne daß ihre Aktivität beeinträchtigt wird.
\end{abstract}

\section{INTRODUCTION}

To comprehend the dynamics of marine ecological systems, it is necessary to investigate changes in their quantitative composition during different seasons of the year. The most sudden and most pronounced fluctuations in physico-chemical conditions and the resulting alterations in number, functional state and behaviour of organisms are observed in the upper regions of the shelf in temperate waters of the Northern hemisphere. There are relatively few papers dealing with seasonal changes in the benthic life of these waters (AuR IWILlius 1895, KNIPOVICH 1902, UsHakov 1925, ZaKs 1927, Gurjanova et al. 1930, Gurjanova 1935, Kuznetzov 1947, 1949, Matveeva 1948, Kussakin 1959, Parker et al. 1965, Kühlmorgen-Hille 1965, Lie 1969, Stripp 1969, Luckens 1970, Propp 1971, and others). Many of these papers treat the littoral zone and only a few of them contain quantitative information concerning seasonal alterations in the populations of the sea bottom. 


\section{MATERIAL AND METHOD}

The bottom and neritic biocoenoses of Possjet Bay in the Sea of Japan were studied using the quantitative diving method by the Laboratory of Marine Investigation of the Zoological Institute of the Academy of Sciences, USSR (Scarlato et al. 1964 ) in the summer of 1962, in spring and autumn 1965, and in winter 1966 (GoliKOV \& SCARLATo 1965, 1971, Golikov 1970). The investigation was conducted on standard sections, perpendicular to the coasts and reaching almost the greatest depths of the region studied $(20-30 \mathrm{~m})$. Before beginning the investigation, the diverinvestigator reviewed the sea bottom in order to obtain a general estimate of the state of the biocoenoses. The populations of each biocoenosis under study were calculated for areas from $100 \mathrm{~m}^{2}$ to $0.05 \mathrm{~m}^{2}$ or $20 \mathrm{~mm}^{2}$, according to the size of organisms and the characteristics of their distribution. Rare organisms of large size were collected from large areas along a measuring rope stretched over the ground. Uneven local distributions of animals and plant aggregations were taken into account. This procedure made it possible to reduce the number of samplings and to estimate correctly the quantitative distribution of organisms on large areas. Smaller organisms, found more often, were collected on many similar areas of the biotope by means of sampling frames, diving "bottom grabs" and "hydrobiological diving bells" with entrance apertures of various sizes, depending on the size of organisms. Samplings from smaller areas were taken more frequently than those from larger areas. In general, the pyramidal system of sampling in quantitative diving method corresponds to the opinion suggested by KINNE (1956) that the size of the samples depends upon the range of variation of the phenomena to be investigated.

In winter, the protected parts of the bay are covered with ice, almost $1 \mathrm{~m}$ thick, while in the open parts drift ice is more common. Due both to poor visibility and the limitation of under-ice mobility of the diver (who had to remain within $50 \mathrm{~m}$ of surface holes), each biotope was investigated during this season over a total distance of only $50 \mathrm{~m}$. In this case, sampling of large and seldom found representatives of the macrofauna was conducted by means of $1 \mathrm{~m}^{2}$ frames, that were used repeatedly. The quantitiative analysis of different parts of the biocoenosis - phytal, epifauna, and infauna - was always conducted with differentiation.

The main results of the summer research and some general conclusions have been published by Golikov \& Scarlato $(1965,1967,1969,1970,1971)$ and Scarlato et al. (1967).

The term "biocoenosis" requires definition. Biocoenosis represents a supraspecific living system consisting of groups of organisms which are characterized by common positions in space and time, common abiotic requirements, inner biotic relations and a defined qualitative and quantitative structure, resulting typically in a domination (in weight or energy) of one, two or a few species over the rest.

The original definition of a biocoenosis by Mönrus (1877), who suggested this term to designate organised associations of organisms in oyster beds, may be interpreted in this very way. As a rule, biocoenoses consist of different parts; thus seabottom biocoenoses may include the phytal (bottom plants and organisms connected 
with them), the epifauna (animals dwelling on the surface of substrates), and the infauna (animals dwelling within the substrate).

The borders between adjacent biocoenoses can be determined by qualitative and quantitative alterations of the dominant species. Biocoenoses, thus interpreted, may often coincide with "belts", "communities" or "groups" (terms suggested by other authors), as long as the dominant forms are not substituted by other forms; substitution testifies to an alteration of environmental conditions and of energy exchange in the ecosystem, and thus indicates the change of the biocoenosis considered.

The diversity of the spaces occupied by a biocoenosis and a possible unevenness of the organismic distribution do not destroy the unity in a biocoenosis as long as the general system of the distribution of dominant species remains undisturbed. This principle is confirmed by seasonal observations on life in biocoenoses. The change of the layer inhabiced by certain organisms (e.g. the migration of organisms from the surface of rocks to crevices or from the surface of stones, under the stones to soft grounds) as well as direct connections between organisms, belonging to the same biocoenosis (food, refuge, etc.) testify to a unity of energy flow and of function in a biocoenosis.

\section{RESULTS AND DISCUSSION}

While studying the composition, structure and distribution of biocoenoses in different seasons of the year, the authors observed considerable successional alterations of biocoenoses, affecting not only quantitative correlations between the species composing them, but influencing their qualitative composition and structure as well. First, the behaviour and the functional state of organisms (especially of those dwelling in warm waters) undergo considerable changes. In spring, when the ice has thawed -. usually in April - the macrophytes begin their intensive development, and many temperate warm-water species begin their spawning period.

By the end of May, when the water temperature rises to $8^{\circ}$ to $12^{\circ} \mathrm{C}$, the majority of the low-boreal species complete their spawning. Many organisms deposit egg capsules and many lay clusters of eggs. The number of larvae of bottom animals in the plankton increases considerably. Representatives of the infauna (e.g., the large bivalve mollusc Anadara broughtony) rise to the upper layer of the ground during spawning and sometimes even emerge onto its surface. Inhabitants of the epifauna (e.g. the prosobranch Homalopoma sangarense, the polychaete Lumbriconereis japonica) move, while spawning, from the ground towards the plants and frequently to the leaves of the sea grass, where they lay egg clusters.

Night divings, during which water and ground were suddenly lit by autonomous lamps, revealed that locomotory activity and migratory movements of many predators (e. g. of sea stars, cephalopods, gastropods, crustaceans and fishes) increased at night time, while certain vegetarian organisms and some detritophages diminished their activity. The general direction of diurnal migrations at night is from greater depths to lesser depths. Changes of locomotory activity and migration direction of bottom animals in the Mediterranean Sea biocoenoses during 24-hour periods were pointed out by CRUMP (1965), ZavodNiK (1965), Ledoyer (1969) and others. 
In June, when the temperature of the water rises to $16^{\circ}$ to $18^{\circ} \mathrm{C}$ and higher, the majority of subtropical species commence spawning. During this time, settling of meroplankton and hatching in species with early spawning periods was observed. The macrophytes begin to grow abundantly. In July and August, the total number of individuals of many species, resulting from the appearance of numerous young of bottom animals, increases suddenly; but at the same time, some old individuals have completed their spawning and begin to die.

At the end of August and in September, in spite of the fact that the water temperature is still high (in protected bays it exceeds $18^{\circ} \mathrm{C}$ ), upper parts of algae and leaves of thermophilic plants, such as Sargassum myiabei and Zostera marina japonica, begin to die. Other small algae grow and develop abundantly, e.g. Codium fragile. The total number of animals dwelling among and on submerged plants begins to decrease, due to their migration towards the ground.

Stormy days occur more often in October, but the water temperature still remains rather high, decreasing towards the end of the month to $6^{\circ} \mathrm{C}$. At this period, a long time before the beginning of frost and ice formation, the most thermophilic animals leave the littoral zone (e.g. Littorina brevicula and L. mandshurica) and the shoals (e.g. the holothurian Stichopus japonicus and the sea scallop Mizubopecten yessoensis), and noticeably diminish their locomotory activity and form aggregations - the former below the maximum ebb-tide level, the latter at depths of 4 to $8 \mathrm{~m}$.

By the end of October, beginning of November, the settling of the young of species with a prolongated spawning period, and of species with two-phase (spring and autumn) spawning is completed. Autumn storms diminish the number of young of shoal-infauna species, which are unable to bury themselves deep enough into the ground, e.g. the edible bivalve mollusc Spisula sachalinensis, whose young are thrown in great quantities onto the beaches.

At the end of summer and in autumn, due to the activity of predators (especially sea stars), a marked decrease occurs in the number of young of many bottom invertebrates, including the edible bivalve mollusc Mizubopecten yessoensis (Golikov \& SCARLATO 1970).

In autumn, many seasonal macrophytes die and some parts of the ground, covered with abundant vegetation in spring and summer, remain devoid of seaweeds.

The first ice appears in December. Due to ebb and tide currents and to stormy weather, drift ice exerts a grating influence on the populations of the littoral zone and of the upper sublittoral down to a depth of $1 \mathrm{~m}$, almost totally destroying sessile animals and plants in certain regions. In this respect, the populations of half-protected bays, covered with solid ice, encounter better conditions and suffer less from storms and low air temperatures during ebb tides.

The thermophilic animal species (virtually all species of subtropical origin and a series of low-boreal species) form aggregations in winter and fall into torpor. For example, Stihopus japonicus in protected bays at depths of 5 to $8 \mathrm{~m}$ on muddy grounds form aggregations with densities of about 40 to 50 specimens $/ \mathrm{m}^{2}$; sometimes they rest on the ground in rows, neither taking food nor moving. Other organisms of the warm waters (e.g. the prosobranch molluscs Tegula rustica, Tritonalia japonica, etc., as well as a series of polychaetes and crustaceans) form specific accumulations under 


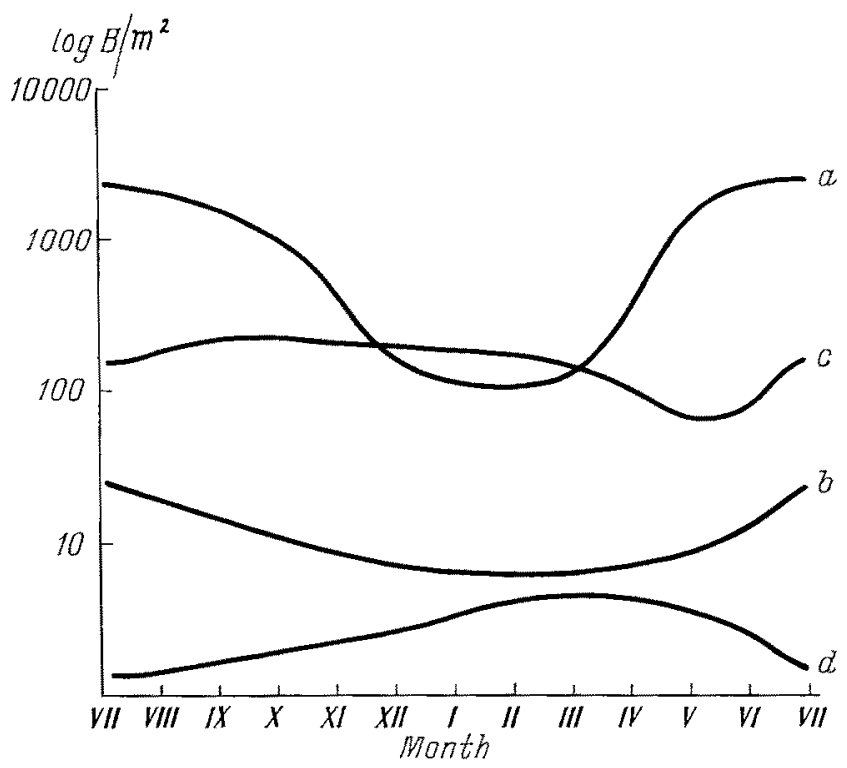

Fig. 1: Seasonal changes in biomass of plants (a), animals of the phytal (b), epifauna (c), and infauna (d) in a protected bay in the biocoenosis Sargassum miyabei. By the ordinate. Log. B: logarithm of biomass per $\mathrm{m}^{2}$

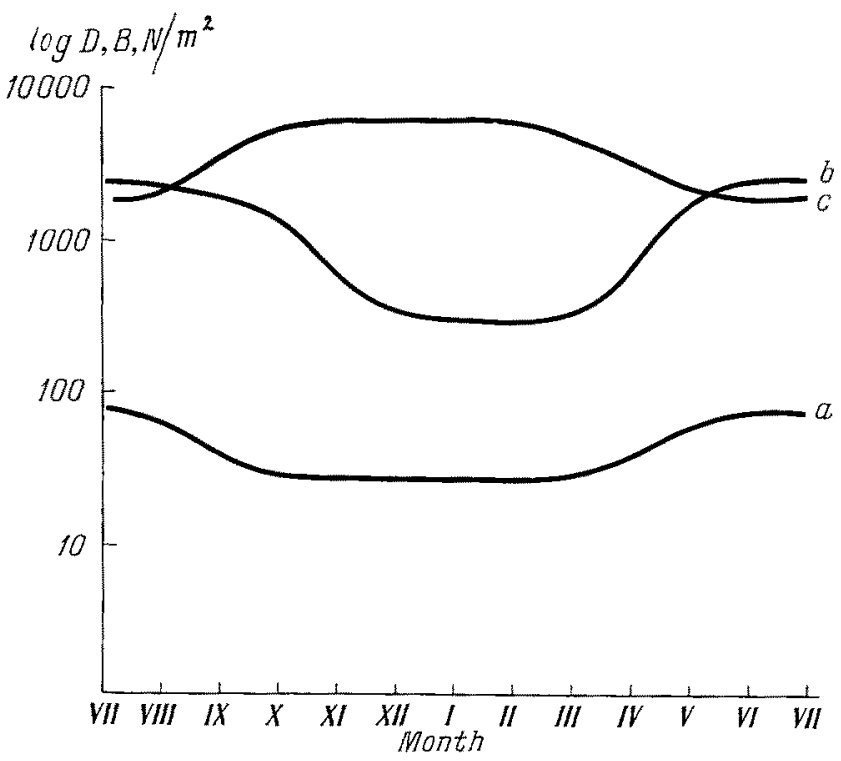

Fig. 2: Seasonal changes in number of species (a), biomass (b), and number of individuals (c) in a half-protected bay at $2 \mathrm{~m}$ depth in the biocoenosis Sargassum miyabei. Log D: logarithm of number of species per $\mathrm{m}^{2} ; \log \mathrm{B}: \log a r i t h m$ of biomass per $\mathrm{m}^{2} ; \log \mathrm{N}: \log$ arithm of number of individuals per $\mathrm{m}^{2}$ 
stones and in crevices, and - once in cold torpor - do not respond to mechanical stimulation. The littoral prosobranch molluscs Littorina brevicula and L. mandsburica, which in winter form accumulations at $0 \mathrm{~m}$ depth, often become frozen in the ice; thawed out in the laboratory, these organisms quickly restore their activity.

The development of warm-water species halts in winter. Less thermophilic species (the widely spread boreal and some low-boreal species) continue to move and to feed. Growth rates decrease in such species, but growth does not stop altogether. With the increase in photoperiod (day length) in February and March, there appear the most eurythermal species of algae (e. g. Desmarestia viridis, Agarum cribrosum); in spring they develop abundantly after the ice has thawed and are especially abundant in summer.

In March, a film forms under the ice consisting of slimy brown and green floating algae, which do not develop considerably and disappear after the ice has thawed. Some species of animals (e. g. the prosobranch mollusc Epheria turrita) begin their spawning under the ice and lay egg clusters, but the pelagic larvae hatch only after the ice thaw and a considerable rise in temperature.

Towards the end of the cold season, species of comparatively cold waters move towards the shoals. Large, moulting Kamchatka crabs occur at depths of 6 to $10 \mathrm{~m}$, as well as some sea stars, Pagurus and other organisms, which can be found at considerable depths during the warm season.

During hydrological srping, with the warming of the water, the activity of all organisms increases, growth rate accelerates and spawning and larval development begin on a large scale.

Already in April, when the water temperature has not yet reached $5^{\circ} \mathrm{C}$, the littoral organisms (e.g. Littorina brevicula) and animals of the upper sublittoral (e.g. Mizubopecten yessoensis) leave their winter habitats and rise to the littoral (the former) including the upper horizon, or migrate to the shoals (the latter).

Apparently the light factor acts as signal for the increase in activity and migration towads the shoals in spring, as well as for migration towards the depths, followed by a decrease in activity, in autumn.

The plants experience the greatest influence of seasonal alterations in biocoenoses; within one year their biomass increases or decreases 14 times (Fig. 1).

The biomass of the plants is largest in summer, decreases considerably towards winter, and swiftly grows in spring. The biomass of animals in phytal and infauna dhanges within one year and may increase 3 to 4 times above the lowest value. The quantity of animals in the phytal decreases towards winter and increases towards summer in accordance with changes in biomass of the algae. The biomass of the infauna increases towards winter, as a result of migration of various animals from the phytal and epifauna under the stones and under the upper layer of shingly and sandy parts of the ground, and it decreases in summer when the animals return to the layers appropriate for them during the active period of their life. The biomass of the epifauna grows towards autumn and diminishes towards spring, primarily due to elimination and, to a lesser extent, to migration. On the whole, the biomass in the above-mentioned biocoenoses undergoes such changes it may become 7 times its lowest value (mostly due to the dying off of the upper parts of Sargassum miyabei in autumn and winter); pop- 


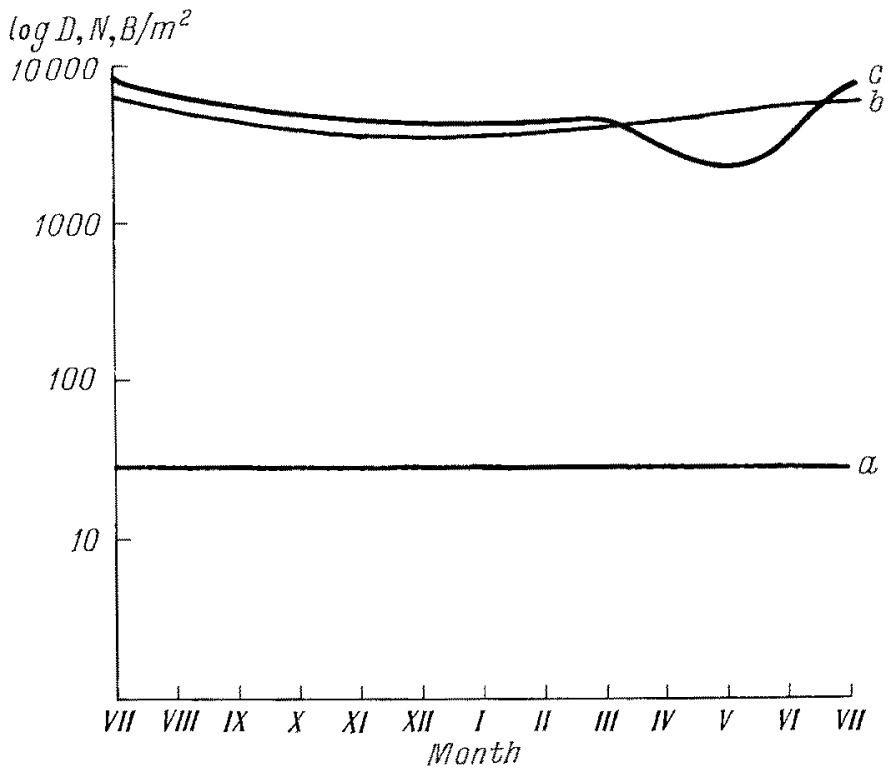

Fig. 3: Seasonal changes in number of species (a), number of individuals (b), and biomass (c) in the biocoenosis Zostera marina japonica in a protected bay at a depth of $1.5 \mathrm{~m}$ on a sandy mud bottom. Log D: logarithm number of species per $\mathrm{m}^{2}$, Log $\mathrm{N}$ : logarithm number of individuals per $\mathrm{m}^{2}, \log \mathrm{B}$ : $\log$ arithm of biomass $(\mathrm{B})$, per $\mathrm{m}^{2}$

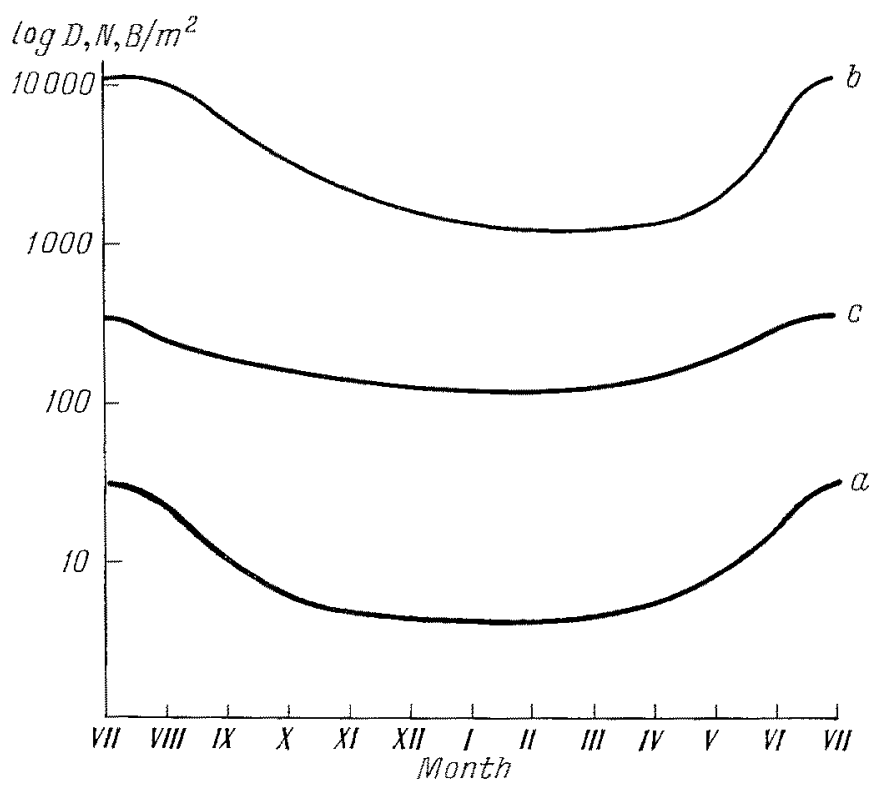

Fig. 4: Seasonal changes in number of species (a), number of individuals (b), and biomass (c) in the biocoenosis Littorina brevicula + Chthamalus dalli in a protected bay, in the middle horizon of the littoral on a stony bottom. Curve designations as in Fig. 2 


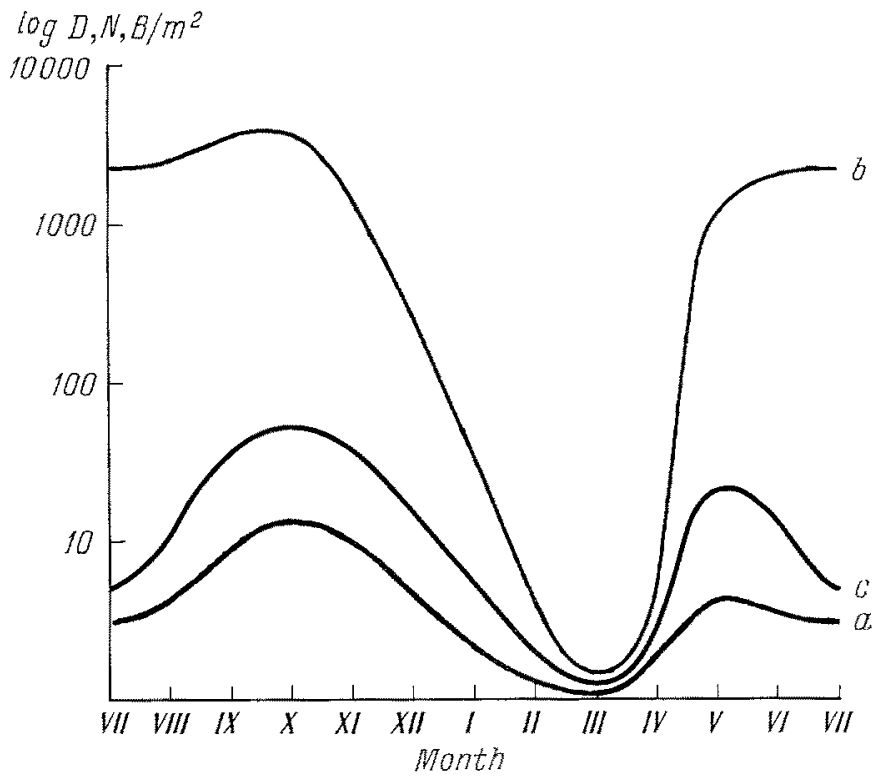

Fig. 5: Seasonal changes in number of species (a), number of individuals (b), and biomass (c) in the biocoenosis Dogielinotus sp. + Umbonium costatum on an open surf sandy beach in the middle horizon of the littoral. Curve designations as in Fig. 2

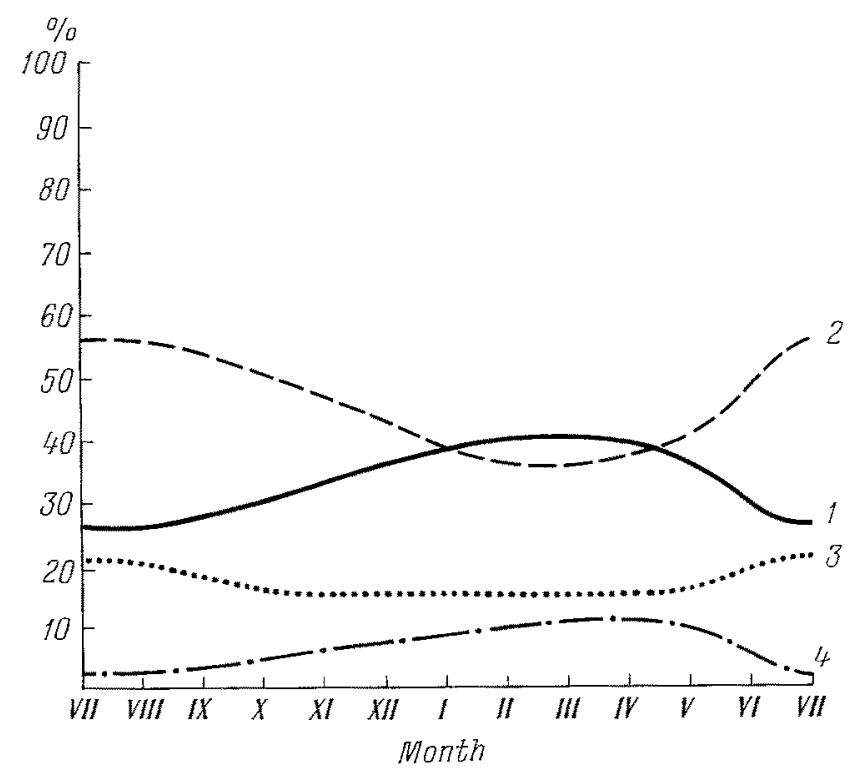

Fig. 6: Seasonal changes in number of different biogeographical groups of species in the biocoenosis Zostera asiatica in an open part of Possjet Bay at $3 \mathrm{~m}$ depth on a sandy-mud ground. Ordinate: percentage of species of a given biogeographical category, composing the biocoenosis in the months stated; 1 : widely distributed boreal species; $2: 10$ w-boreal species; 3 : subtropical species; 4 : boreal-arctic species 
ulation density may increase to 5 times its original value; and the species number (mostly due to migration) may double (Fig. 2).

In biocoenoses with smaller seasonal fluctuations in biomass of dominant species, seasonal successions of composition and population abundance are also considerably smaller, and the most variable index of a biocoenosis - the number of individuals may become less than 3 times its lowest value (Fig. 3).

In the inner Sea of Japan, the biomass and population density of the subtropical, background-forming species Sargassum serratifolium and of the fauna may increase to 10 times their lowest value (MukaI 1971). Annual fluctuations of the same indices of the macrofauna and meiofauna in the Helgoland Bay (North Sea), on sandy and muddy ground, where the dominant species are not background-forming and do not change their biomass to such a degree, are smaller; they amount to 1.5 to 2.5 times their initial value (KüHLMORgEN-HrLle 1965, STRIpp 1969, and others).

The data outlined and studies on other biocoenoses confirm the fact that the degree of seasonal changes in biocoenoses greatly depends upon seasonal fluctuations in the number and biomass of the dominant background-forming species, giving shelter, substratum and nourishment to many organisms connected with them.

Seasonal successions between tide marks are more extreme than in the sublittoral. In protected bays which are covered with permanent ice in winter, seasonal fluctuations in number of individuals, biomass and number of species are less pronounced than at the same littoral levels in open parts subjected to mechanical abrasion of drifting ice and to air temperatures below zero during tidal exposure (Figs 4, 5).

Seasonal alternations in the number of species within biocoenoses result from death of organisms with a short life span and, to a large extent, from migration.

Low-boreal and subtropical species attain their maximum variety in warmed water layers at depths of 0 to $5 \mathrm{~m}$. Their number decreases in winter, partly due to migration from the littoral and the upper sublittoral $(0$ to $1 \mathrm{~m})$ towards greater depths ( 3 to $10 \mathrm{~m}$ ). In contrast, species from comparatively cold waters, boreal and boreoarctic species rise to the shoals in winter (up to 2 to $2 \mathrm{~m}$ ), and at the beginning of summer they migrate to cool waters and towards greater depths (below $20 \mathrm{~m}$ ) (Fig. 6).

The number and composition of species in biocoenoses of the upper regions of the shelf may change and become more than twice as large (or twice as small). Dominant background-forming species, determining the character of a biocoenosis, preserve as a rule their leading position. However, in biocoenoses in which seasonal macrophytes or migrating forms dominate, seasonal successions sometimes go so far as to substitute the dominant forms; this phenomenon re-occurs regularly in certain seasons of the year.

Thus, dominant forms of some biocoenoses of the stony littoral (Littorina brevicula and $L$. mandshurica) disappear completely in winter and migrate to depths below $0 \mathrm{~m}$, where they abide in torpor because of the cold.

Further studies on seasonal changes in the distribution and structure of biocoenoses may yield more information necessary to understand the organisation of life in the sea and to promote the theory of synecology. 


\section{SUMMARY}

1. Bottom biocoenoses in Possjet Bay (Sea of Japan) have been studied employing the quantitative diving method of hydrobiological investigation in different seasons of the year.

2. The investigations have revealed the existence of considerable seasonal successions in biocoenoses. These successions affect not only the number of populations and their age structure, but also influence the qualitative composition of the biocoenoses.

3. The responses are most pronounced in warm-water species; they initiate migrations preceding spawning in spring and summer, and torpor in the autumn-winter period. Migrations occur long before the temperature attains values necessary for successful reproduction, and long before it falls to the level causing torpor with cold. Apparently the primary factor initiating the migrations or changes in behaviour is the light.

4. Species of different biogeographical origin respond to definite temperatures for spawning and for settling of young.

5. The number of individuals per species undergoes considerable seasonal changes. Within the majority of species it reaches its maximum in summer and autumn, due to the appearance of the young, and its minimum in winter and spring, due to mass elimination.

6. The degree of seasonal changes in bottom biocoenoses of the upper regions of the shelf is highest in submerged plants; it diminishes in the following order: inhabitants of the phytal epifauna, animals with a short life cycle, animals with a long life cycle, vegetarian species, predators.

7. To a considerable extent, seasonal successions in biocoenoses depend upon fluctuations in biomass of the dominant background-forming species. Seasonal variations comprising 7 or 10 times larger or smaller biomasses are observed in biocoenoses in which the dominant background-forming species reveal pronounced changes in their biomass within a one-year period; relatively small seasonal variations ( 2 or 3 fold) are characteristic of biocoenoses with dominant species which are not background-forming or which change their biomass during the seasons only slightly.

8. Biocoenoses of the littoral zone change much more than biocoenoses located below the tidal level. Biocoenoses of the littoral zone and of shoals that are covered with a solid layer of ice during winter are less liable to seasonal successions than biocoenoses of open unprotected beaches that remain free from ice during the cold season or are intermittently covered with drift ice.

9. Before the cold season begins, warm-water species migrate from the littoral to depths below $0 \mathrm{~m}$, form aggregations and fall into torpor with cold, when the temperature falls further. Cold-water species remain active in winter; some of them rise from more than $20 \mathrm{~m}$ to depths of about 2 or $3 \mathrm{~m}$, temporarily joining the shoal biocoenoses. In some more changeable biocoenoses of the littoral, successions result in the substitution of the dominant forms. 
10. All biocoenoses studied are stationary; in each season they exhibit a more or less definite number of species, biomass and specific composition.

Acknowledgement. The authors are deeply indebted to Professor Dr. O. KInNe, Leading Director and Professor of the Biologische Anstalt Helgoland, for critically going through our manuscript.

\section{LITERATURE CITED}

Aurrvillius, C. W., 1895. Littoralfaunan förhallanden vid tiden för hafvets isläggning Ofv. Ak. Förh., 52, 133-150.

Crump, K. G., 1965. The diurnal activity of holothurians. In: Symposium Underwater Association, Malta. Ed. by J. N. LythGoE \& J. D. Woods. 43-45.

GrsLEN, T., 1930. Epibioses of the Gulmar Fjord I-II. A study in marine sociology (Kristinbergs Zool. St., 1877-1927). SkrSer. K. svenska VetenskAkad. 1929 (3), 1-123; 1930 (4), 1-380.

Golrkov, A. N., 1970. Seasonal dynamics of number and productive properties of some biocoenoses of the upper region of the shelf at the coasts of Southern Primorje. Biological processes in sea and continental reservoirs. (Russ.) Conf. All-Union Hydrobiol. Soc. 2, $82-83$.

- \& Scarlato, O. A., 1965. Hydrobiological explorations in the Possjet Bay by means of the SCUBA diving technique. (Russ.) Issled. Fauny Morei 3 (11), 5-19.

- 1967. Ecology of bottom biocoenoses in the Possjet Bay (the Sea of Japan) and the peculiarities of their distribution in connection with physical and chemical conditions of the habitat. Helgoländer wiss. Meeresunters. 15, 193-201.

- 1969. Scientific principles of organisation of controllable submarine farms, devised on the basis of light diving technique. (Russ.) Section of submarine investigation of the oceanography committee of the Acad. Sci. of the USSR (Nauka), 60-66.

- - 1970. Abundance, dynamics and production properties of population of edible bivalves Mizubopecten yessoensis and Spisula sacbalinensis related to the problem of organization of controllable submarine farms at the Western shores of the Sea of Japan. Helgoländer wiss. Meeresunters. 20, 498-513.

- - 1971. Some results of hydrobiological diving investigations of the Possjet Bay (the Sea of Japan). (Russ.) Gidrobiol. Zh. 7 (5), 32-37.

Gurjanova, E. F., 1935. The Commandor Islands and their marine coastal fauna, and flora. (Russ.) Priroda 11, 64-72.

- Zaks, I. G. \& Ushakov, P. V., 1930. The littoral of the Kola Bay. III, Existence condition. (Russ.) Trudy leningr. Obshd. Estest. 59 (2), 2-107.

KINNE, O., 1956. A programmatic study of comparative biology of marine and brackish water animals. Colloque int. Biol. mar. Stn Biol. de Roscoff, 87-92.

KNIPovich, N. M., 1902. Expedition with the view of trade investigation of the Murman coasts. (Russ.) Moskau, 605 pp.

KÜHLMORGEN-HrLle, G., 1965. Quantitative und qualitative Veränderungen der Bodenfauna der Kieler Bucht in den Jahren 1953-1965. Kieler Meeresforsch. 21 (2), 167-191.

KuzNetzov, V. V., 1947. The influence of the ice cover on the morphology of the population of the littoral zone. (Russ.) Dokl. Akad. Nauk SSSR 58, 163-166.

- 1949. The influence of the ice-cover on the morphology, fauna and flora of the White Sea littoral. (Russ.) Rab. morsk. biol. St. Karelo-Finsk. gos. Univ. 1, 44-57.

Kussarrn, O. G., 1958. Seasonal changes in the littoral of the Southern Kuril Islands. (Russ.) Vest. leningr. Univ. (Biol.) 1, 116-130.

LEDOXER, M., 1969. Ecologie de la faune vagile des biotopes méditerranéens acessibles en scaphandre autonome. V. Etude des phenomenes nycthemeranx. Les variations nycthémérales des populations animals dans les biotopes. Tethys 1, 291-308. 
Lre, U., 1968. A quantitative study of benthic infauna in Puget Sound, Washington, U.S.A., in 1963-1964, Fisk.Dir. Skr. (Havundersøkelser) 14, 229-556.

Luckens, P. A., 1970. Seasonal distributional variation within a limited shore area at Asamushi. Sci. Rep. Tôhoku Univ. (Ser. 4) 35, 161-170.

MatveEva, T. A., 1948. Seasonal changes of littoral population on stony fauna in the DalnoZelenetzky inlet. (Russ.) Trudy murmansk. biol. Sta. 1, 121-145.

Mörius, K., 1877. Die Auster und die Austern-Wirtschaft. Wiegandt, Berlin, 126 pp.

Mukar, H., 1971. The phytal animals on the thalli of Sargassum serratifolium in the Sargassum region, with reference to their seasonal fluctuations. Mar. Biol. 8, 170-182.

Parker, R. H., Nagle, J. S., Williams, A. B. \& Kaufman, K., 1965. Seasonal aspects of Hydley harbour benthic ecology. Biol. Bull. mar. biol. Lab., Woods Hole 129, 418.

Propp, M. V., 1971. The ecology of coastal bottom communities of the Murman coast (the Barents Sea). After the materials of hydrobiological diving works. (Russ.) Leningrad (izd. Nauka), 1-128.

Scarlato, O. A., Golikov, A. N. \& Gruzov, E. N., 1964. The SCUBA diving technique for hydrobiological investigations. (Russ.) Okeanologija 4,707-719.

- - Vasilenko, S. V., Tzvetkova, N. L., Gruzov, E. N. \& Nesis, K. N., 1967. Composition, structure and distribution of bottom biocoenoses in the coastal waters of the Possjet Bay (the Sea of Japan). (Russ.) Issled. Fauny Morei 5 (13), 6-61.

STRIPP, K., 1969. Jahreszeitliche Fluktuationen von Makrofauna und Meiofauna in der Helgoländer Bucht. Veröff. Inst. Meeresforsch. Bremerh. 12, 65-94.

Ushakov, P. V., 1925. Seasonal alteration in the littoral of the Kola Bay. (Russ.) Trudy leningr. Obshch. Estest. 54 (1), 47-72.

Zaks, I. G., 1927. Preliminary data on the distribution of fauna and flora in the incoast zone of the Bay of Peter the Great (the Sea of Japan). (Russ.) Proc. 1st conf. on studying the productive forces of the Far East 4, 213-248.

ZavodniK, N., 1965. Contribution à la connaissance de la faune vagile, poissons notamment, des herbiers de Zostera en Adriatique du Nord. Rapp. P.-v. Réun. Commn. int. Explor. scient. Mer. Méditerr. 18, 99-100.

First author's address: Dr. A. N. Gourkov

Zoological Institute of the Academy of Sciences

Leningrad V-164

USSR 